\title{
Retailer Service Quality and Customer Loyalty: Empirical Evidence in Vietnam
}

\author{
Nguyen Thu $\mathrm{Ha}^{1}$, Nguyen Hue Minh ${ }^{1,2}$, Phan Chi $\mathrm{Anh}^{3} \&$ Yoshiki Matsui ${ }^{2}$ \\ ${ }^{1}$ Faculty of Business Administration, University of Economics and Business, Vietnam National University, \\ Vietnam \\ ${ }^{2}$ College of Business Administration, Yokohama National University, Japan \\ ${ }^{3}$ Vietnam-Japan University, Vietnam National University, Vietnam \\ Correspondence: Nguyen Thu Ha, Faculty of Business Administration, University of Economics and Business, \\ Vietnam National University, Vietnam. Tel: 84-98-289-8582. E-mail: hant@vnu.edu.vn
}

Received: August 21, 2014 Accepted: January 1, 2015 Online Published: January 14, 2015

doi:10.5539/ass.v11n4p90 URL: http://dx.doi.org/10.5539/ass.v11n4p90

\begin{abstract}
This study investigates the relationship between retailer service quality and customer loyalty by conducting questionnaire survey on 664 buyers in several supermarkets in Vietnam. This questionnaire was constructed with 49 retail service quality items covering 6 service quality dimensions namely Physical aspects, Reliability, Personal Interaction, Problem solving and Policy and Information of goods, and 2 customer loyalty items. Statistical analysis results indicate the significant link between customer loyalty and such dimensions of service quality as Problem solving, Policy and Personal Interaction. From these findings, both managerial and theoretical implications have been discussed.
\end{abstract}

Keywords: service quality, retail industry, supermarket

\section{Introduction}

Due to undeniable impacts on organizations' performance, customer satisfaction, customer loyalty, and in turn, profitability, service quality has attracted great attention from practitioners, managers and researchers all over the world. That is the reason why studying on how to define, model, measure, collect and analysis data of service quality, has been leading to development of sound base for the researchers (Seth et al., 2005).

In Vietnam, the increasing trend of average income per capital offering many opportunities for both domestic and foreign retail enterprises. Especially, according to Vietnam Ministry of Industry and Trade, Vietnam, after joining in the World Trade Organization (WTO), committed to open its retail market to foreign investors, and allow foreign retailers to set up $100 \%$ foreign owned retail enterprises. In spite of the domination of traditional channels of retail service providers, many leading international retail brands have been making huge investment in Vietnam. Many forms of retail service providers have been developed such as business center, supermarket, grocery store, convenient store, and so on. By the end of 2013, there are 724 supermarkets in Vietnam in which 97 supermarkets are located in Hanoi (General Statistics Office of Vietnam, 2013). Experiencing the highest growth rate in the world since 2001 with $25 \%$ annual increase on average, Vietnam is currently considered as one of the most dynamic economy in South East Asia which possesses enormous advantages to attract retailers.

This situation raises a question about how retail businesses can perform better in this highly competitive market. Attaining customer loyalty which is fruitful sources of profits could be a potential answer for this question. To address this need, the study aims to examine service quality as well as its impacts on customer loyalty to find out which components of service quality significantly contribute to improve customer loyalty for retail businesses in Vietnam.

\section{Literature Review}

\subsection{Service Quality and Service Quality Models}

Gronroos (1984) and Parasuraman et al. (1985) proposed that service quality is a function of the differences 
between customers' expectation and their perception of the actual service received. Customers are satisfied when the perceived value meets or exceeds their expectation. In contrast, they are dissatisfied when they feel the perceived value below their expectation. This definition is accepted by a majority of academicians as well as practitioners and widely used to address research and business issues.

It cannot be denied that measuring service quality is obviously more difficult than goods' quality. The reason why is that unlike physical products, service product has a fewer tangible cues (Parasuraman et al., 1985) and also requires higher consumer involvement in the consumption process (Gronroos, 1984). Gronroos (1984) found that three dimensions including technical quality, functional quality and corporate image were critical component used to assess service quality. Then, Parasuraman et al. (1985) proposed the conceptual model namely SERVQUAL which has become the most widely used model to measure service quality for many years. This model presented 10 key service quality aspects including Reliability, Competence, Responsiveness, Communication, Access, Credibility, Courtesy, Tangibles, Understanding the customer, and Security. By 1988, Parasuraman refined these 10 dimensions into only five dimensions including Reliability, Responsiveness, Assurance, Empathy, and Tangibles.

Table 1. Dimensions measuring service quality of SERVQUAL

\begin{tabular}{ll}
\hline Dimensions & Definitions \\
\hline Reliability & Ability to perform dependably and accurately the service as promised \\
Responsiveness & Willingness to provide prompt services and help customers \\
Assurance & Staff's knowledge and courtesy as well as their ability to inspire confidence and trust \\
Empathy & Caring and giving individual attention to customers. \\
Tangibles & Physical facilities, materials, equipments, and appearance of staff \\
\hline
\end{tabular}

Source: Parasuraman, Zeithaml, \& Berry, 1988, p. 23

Despite SERVQUAL-the multiple-item scale has been applied to measure quality of many different service types; there are some limitations and also criticisms on its confusion (Babakus \& Mangold, 1989; Finn \& Lamb, 1991; Pitt, Oosthuizen, \& Morris, 1992; Spreng \& Singh, 1993). In 1992, Cronin and Taylor developed SERVPERF scale to measure service quality. Unlike SERVQUAL scale, SERPVPERF maintains only the perception of service quality through the use of 22 perception items. The advantage of SERVPERF scale has been demonstrated in various studies including those by Brady et al. (2002), Lee et al. (2000), and Avkiran (1999).

Although SERVQUAL has been empirically tested in a number of studies, it has not been validated in a retail industry. Finn and Lamb (1991) examined the usefulness of this scale in four different types of retail stores. Results did not support the proposition that the scale can be used to assess perceived service quality in retail setting. Dabholkar et al. (1996) developed Retail Service Quality Scale (RSQS) based on SERVPERF scale. This scale comprises of 28 items of which 17 items were from SERVPERF and 11 items were developed by qualitative research. These 28 question items belong to five service quality dimensions, namely Physical Aspects, Reliability, Personal Interaction, Problem Solving, and Policy. This scale was widely adopted to examine service quality in retail sector in many studies such as Das et al. (2008), Kaul (2007), Wong \& Sohal (2002), Mehta et al. (2000), Bloemer et al. (1998), Christo \& Terblanche (1997).

Table 2. Dimensions measuring service quality of RSQS

\begin{tabular}{ll}
\hline Dimensions & Definitions \\
\hline Physical aspects & Appearance and Convenience of retail store \\
Reliability & Retailers do the right things and do as they promised \\
Personal interaction & Employees are courteous and can inspire confidence in customers \\
Problem solving & Employees' ability to handle customer' complaints, returns and exchanges \\
Policy & Store policy on parking, operation hours, merchandise quality, credit cards. \\
\hline
\end{tabular}

Source: Dabholkar et al., 1996, pp. 6-7 
Dimensions used in Dabholkar's model are stressed as important components to measure retail service quality in the literature. The convenience of shopping such as store layout also is demonstrated as one of the service quality dimensions in retailing which impacts on customers' perceptions (Gutman \& Alden, 1985; Hummel \& Savitt, 1988; Oliver, 1981). Moreover, Westbrook (1981) found that customers were rather sensitive to the way retailers treat to their problems. Mazursky and Jacoby (1985) also showed that good policies of returning and exchanging merchandise as well as the credit and charge account were important to retail customers. Furthermore, Baker, Grewal, and Parasuraman (1994) also mentioned that store environment comprising of ambient attributes, design attributes and social attributes played important role in evaluating retail service quality of customers. Besides, other retail service quality dimensions such as convenient parking, quality of merchandise were examined in the empirical study of Oliver (1981).

\subsection{Customer Loyalty}

It is no doubt that service quality, customer satisfaction and customer loyalty have been becoming obviously important element of successful advantages for service providers (Rust et al., 1995; Zeithaml, 1996, Kitapci et al., 2013). Service quality and its components are stressed as antecedent to customer satisfaction and customer loyalty. In turn, with the mediating role of customer satisfaction, customer loyalty which is a strong determinant of profitability is the final target of all businesses.

In the late of 1980s, results of studies on customer satisfaction reflected the detection of customer loyalty or complaints for products/services. Auh \& Johnson (2005) defined store loyalty as the possibility or tendency of repurchasing a specific product or service. It revealed that store loyalty was a direct result of customer satisfaction, and customer satisfaction played a role as an essential catalyst for developing loyalty. Gee et al. (2008) listed three advantages of customer loyalty: Firstly, serving service cost for a loyal customer is less than for a new customer. This advantage was also highlighted in studies by Ndubisi et al. (2005) which claimed that the cost of serving a loyal customer is five or six times less than serving a new customer. Secondly, loyal customers are willing to pay higher price for a set of services; and thirdly, a loyal customer will act as an effective word-of-mouth marketing channel for the company.

Particularly, there are some studies concerning service quality and customer loyalty topics in Vietnamese retail industry such as Service quality and loyalty: A study of supermarkets in Ho Chi Minh city by Trang (2006); Determinants of retail service quality-a study of supermarkets in Vietnam by Nhat \& Hau (2007). Trang (2006) examined the relationships between the service quality of supermarkets and the customer satisfaction and loyalty by using a sample of 318 supermarket shoppers in Ho Chi Minh City. The methodology of this study has been combined of Retail Service Quality Scale (RSQS) and qualitative research of author. The results indicated that five dimensions comprising of the Quality of merchandise, Service personnel, Layout of retail store, Appearance and Safety were important factors that made customers satisfied and loyal to a supermarket. Nhat \& Hau (2007) tested RSQS at 440 shoppers in various supermarkets in Ho Chi Minh City. The findings showed that 4 factors namely Physical Aspects, Service Personnel, Policy and Reliability have impact on service quality in supermarkets. These studies, however, confined themselves on several specific regions. Therefore, more intensive studies are necessary.

To address this need, the study, based on Dabholkar's model with some customizations, aims to empirically investigate the relationship between service quality and customer loyalty in Vietnamese supermarkets.

Table 3. Summary of several studies on retail service quality measurement

\begin{tabular}{|c|c|c|c|c|c|c|}
\hline Authors & & $\begin{array}{l}\text { Research } \\
\text { settings }\end{array}$ & Study sample (s) & Instrument & & Factor structure/Key findings \\
\hline $\begin{array}{l}\text { Dabholkar } \\
\text { al. (1996) }\end{array}$ & et & $\begin{array}{l}\text { Southeastern } \\
\text { USA }\end{array}$ & $\begin{array}{l}227 \text { respondents of } 7 \\
\text { stores from } 2 \\
\text { department } \\
\text { chains }\end{array}$ & $\begin{array}{l}\text { Retail Service } \\
\text { Scale }\end{array}$ & Quality & $\begin{array}{l}\text { A hierarchical structure for Retail } \\
\text { Service Quality was proposed } \\
\text { including of five basic dimensions: } \\
\text { Reliability, Physical Aspects, Problem } \\
\text { Solving, Personal Interaction, and } \\
\text { Policy. Among which, three } \\
\text { dimensions have two sub-dimensions } \\
\text { each. }\end{array}$ \\
\hline Christo & $\&$ & South Africa & Hypermarkets & Retail service & quality & The findings demonstrated that RSQS \\
\hline
\end{tabular}




\begin{tabular}{|c|c|c|c|c|}
\hline Authors & $\begin{array}{l}\text { Research } \\
\text { settings }\end{array}$ & Study sample (s) & Instrument & Factor structure/Key findings \\
\hline $\begin{array}{l}\text { Terblanche } \\
\text { (1997) }\end{array}$ & & shoppers & $\begin{array}{l}\text { scale in Dabholkar et al., } \\
1996\end{array}$ & $\begin{array}{l}\text { proposed by Dabholkar et al. (1996) } \\
\text { has reasonable fit. }\end{array}$ \\
\hline $\begin{array}{l}\text { Boshoff and } \\
\text { Terblanche } \\
\text { (1997). }\end{array}$ & $\begin{array}{l}\text { South } \\
\text { Africa. }\end{array}$ & & $\begin{array}{l}\text { RSQS (Dabholkar et al., } \\
\text { 1996) }\end{array}$ & $\begin{array}{l}\text { The findings supported the } \\
\text { applicability of Retail service quality } \\
\text { scale in the context of department } \\
\text { stores, specialty stores and } \\
\text { hypermarkets }\end{array}$ \\
\hline & & & & $\begin{array}{l}\text { RSQS was found to be fit in a } \\
\text { supermarket environment. }\end{array}$ \\
\hline $\begin{array}{l}\text { Mehta et al. } \\
(2000)\end{array}$ & Singapore & $\begin{array}{lr}\text { Customers } & \text { of } \\
\text { electronic } & \text { goods } \\
\text { retailers } & \text { and }\end{array}$ & $\begin{array}{l}\text { RSQS (Dabholkar et al., } \\
\text { 1996) and SERVPERF }\end{array}$ & $\begin{array}{l}\text { SERVPERF was better for measuring } \\
\text { retail service quality because the } \\
\text { service element is more prevalent. }\end{array}$ \\
\hline & & supermarkets & & $\begin{array}{l}\text { Five new dimensions were presented } \\
\text { from combining of RSQS and } \\
\text { SERVPERF. }\end{array}$ \\
\hline $\begin{array}{l}\text { Trang, N. T. } \\
\text { M. }(2006)\end{array}$ & Vietnam & $\begin{array}{l}318 \text { supermarket } \\
\text { shoppers in HCMC }\end{array}$ & $\begin{array}{l}\text { RSQS and qualitative } \\
\text { research of author }\end{array}$ & $\begin{array}{l}\text { The results indicated that five retail } \\
\text { service quality dimensions comprising } \\
\text { of the Quality of merchandise, Service } \\
\text { personnel, Layout of retail store, } \\
\text { Appearance and Safety have } \\
\text { significant impacts on customer } \\
\text { satisfaction and customer loyalty. }\end{array}$ \\
\hline Kaul S. (2007) & India & $\begin{array}{l}144 \text { shoppers at large } \\
\text { format apparel stores } \\
\text { in Bangalore }\end{array}$ & $\begin{array}{l}\text { RSQS (Dabholkar et al., } \\
\text { 1996) }\end{array}$ & $\begin{array}{l}\text { The RSQS dimensions and } \\
\text { sub-dimensions are not clearly } \\
\text { identifiable. The dimension of } \\
\text { 'Physical Appearance' is the only one } \\
\text { that is relatively clear. All other } \\
\text { dimensions are ill-defined. }\end{array}$ \\
\hline & & & & $\begin{array}{l}\text { RSQS is inappropriate for application } \\
\text { in Indian retail }\end{array}$ \\
\hline $\begin{array}{l}\text { Nhat, N. D. } \\
\text { D., and Hau, } \\
\text { L. N. }\end{array}$ & Vietnam & $\begin{array}{l}440 \text { shoppers in } \\
\text { various supermarkets } \\
\text { in } \mathrm{HCMC}\end{array}$ & $\begin{array}{l}\text { RSQS (Dabholkar et al., } \\
\text { 1996) }\end{array}$ & $\begin{array}{l}\text { The findings showed that } 4 \text { factors } \\
\text { namely Physical Aspects, Service } \\
\text { Personnel, Policy and Reliability have } \\
\text { impact to service quality in } \\
\text { supermarkets. }\end{array}$ \\
\hline $\begin{array}{l}\text { Das et al., } \\
(2008)\end{array}$ & Kazakhstan & $\begin{array}{l}220 \text { respondents } \\
\text { collected from the } \\
\text { Almaty city of } \\
\text { Kazakhstan. }\end{array}$ & $\begin{array}{l}\text { RSQS (Dabholkar et al., } \\
\text { 1996) }\end{array}$ & $\begin{array}{l}\text { The findings indicated that there was a } \\
\text { good fit of the RSQS dimensions and } \\
\text { the items }\end{array}$ \\
\hline $\begin{array}{l}\text { Bloemer et al. } \\
\text { (1998) }\end{array}$ & Belgium & $\begin{array}{l}708 \text { respondents } \\
\text { from a super market, } \\
\text { two competitive } \\
\text { providers in each } \\
\text { entertainment, fast } \\
\text { food and health care } \\
\text { category }\end{array}$ & $\begin{array}{l}\text { SERVPERF by Cronin } \\
\text { and Taylor (1992). }\end{array}$ & $\begin{array}{l}22 \text { items with cross-level design. } \\
\text { Negative linkage between } \\
\text { organizational commitment and } \\
\text { perceived service quality; role } \\
\text { ambiguity and both organizational } \\
\text { commitment and commitment to } \\
\text { quality; commitment to the } \\
\text { organization and customer perceived } \\
\text { service quality and customer loyalty. } \\
\text { Perceived service quality seems to be } \\
\text { the key to customer loyalty. }\end{array}$ \\
\hline $\begin{array}{l}\text { Caruana, A. } \\
(2002)\end{array}$ & Malta & $\begin{array}{l}194 \quad \text { banking } \\
\text { customers }\end{array}$ & $\begin{array}{l}\text { Three } \\
\text { instruments-service } \\
\text { loyalty (Gremler \& } \\
\text { Brown, 1996), service } \\
\text { quality (Parasuraman et }\end{array}$ & $\begin{array}{l}37 \text { items in a mediation model linking } \\
\text { service quality to customer loyalty via } \\
\text { the mediate role of customer } \\
\text { satisfaction. The effects of several } \\
\text { demographic indicators on service }\end{array}$ \\
\hline
\end{tabular}




\begin{tabular}{|c|c|c|c|c|}
\hline Authors & \multirow[t]{2}{*}{$\begin{array}{l}\text { Research } \\
\text { settings }\end{array}$} & \multirow[t]{2}{*}{ Study sample (s) } & \multirow{2}{*}{$\begin{array}{l}\text { Instrument } \\
\text { al., 1994), customer } \\
\text { satisfaction (Bitner \& } \\
\text { Hubbert, 1994) }\end{array}$} & \multirow{2}{*}{$\begin{array}{l}\text { Factor structure/Key findings } \\
\text { loyalty such as education, age, and so } \\
\text { on are discussed. }\end{array}$} \\
\hline & & & & \\
\hline $\begin{array}{l}\text { Wong, } \\
\text { Sohal, } \\
(2002)\end{array}$ & $\begin{array}{l}\text { Victoria, } \\
\text { Australia }\end{array}$ & 1,261 respondents & $\begin{array}{l}\text { Modified version of } \\
\text { SERVQUAL scale } \\
\text { (Parasuraman et al., } \\
\text { 1988) }\end{array}$ & $\begin{array}{l}29 \text { items, five dimensions in a } \\
\text { conceptual model reflecting } \\
\text { relationship between dimensions of } \\
\text { service quality and customer loyalty. } \\
\text { Positive correlation between customer } \\
\text { loyalty and service quality, especially } \\
\text { at company level with the most } \\
\text { significant predictor is tangibles, while } \\
\text { at interpersonal level it is empathy. }\end{array}$ \\
\hline $\begin{array}{l}\text { Ponirin et al. } \\
\text { (2009) }\end{array}$ & Indonesia & $\begin{array}{l}3 \text { e-stores and } 324 \\
\text { Indonesian } \\
\text { e-customers of the } \\
\text { last } 12 \text { months in } \\
2001 / 2002\end{array}$ & $\begin{array}{l}\text { New set of survey } \\
\text { questions developed by } \\
\text { the authors }\end{array}$ & $\begin{array}{l}\text { Six determinants of performance based } \\
\text { service quality for an e-store were } \\
\text { tested for validity and reliability } \\
\text { The reliability and validity tests were } \\
\text { conducted for } 6 \text { determinants of } \\
\text { service quality for e-stores. The results } \\
\text { illustrated a strong and positive } \\
\text { linkage between service quality and } \\
\text { customer loyalty of the e-stores. }\end{array}$ \\
\hline $\begin{array}{l}\text { Beneke et al. } \\
\text { (2012) }\end{array}$ & South Africa & 307 respondents & $\begin{array}{l}\text { RSQS (Dabholkar et al., } \\
\text { 1996) }\end{array}$ & $\begin{array}{l}\text { The results revealed a direct } \\
\text { relationship between Physical Aspects } \\
\text { and Personal Interaction with } \\
\text { Customer Satisfaction. In addition, } \\
\text { customer satisfaction also positively } \\
\text { associated with store loyalty. }\end{array}$ \\
\hline $\begin{array}{l}\text { Kitapci, } \\
(2013)\end{array}$ & Turkey & $\begin{array}{l}505 \quad \text { supermarket } \\
\text { customers }\end{array}$ & $\begin{array}{l}\text { Measuring service } \\
\text { quality with } 17 \text { items } \\
\text { adapted from Kueh and } \\
\text { Voon (2007); Measuring } \\
\text { customer satisfaction } \\
\text { and customer loyalty } \\
\text { adapted from Laroche et } \\
\text { al. (2004) and Nam } \\
(2008)\end{array}$ & $\begin{array}{l}\text { Paths model between the five } \\
\text { SERVQUAL dimensions } \\
\text { (Parasuraman et al., 1985). Tangibility, } \\
\text { Responsiveness, Empathy, and } \\
\text { Assurance are factors that had positive } \\
\text { relation to customer satisfaction, } \\
\text { which in turn, positively related to } \\
\text { customer loyalty. }\end{array}$ \\
\hline
\end{tabular}

\subsection{Analytical Framework}

RSQS has been widely used to measure service quality in retail industry at different countries. The scale was designed to measure five distinct dimensions: 1-Physical aspects, 2-Reliability, 3-Personal Interaction, 4-Problem solving and 5-Policy. Among which, Physical aspects has 2 sub-dimensions namely Appearance and Convenience, Reliability also has 2 sub-dimensions namely Promises and Doing it right.

Additionally, the differences in culture also impact to measure quality in a service sector (Ueltshy \& Krampf, 2001). When measuring retail service quality in Vietnam environment, we referred "Regulation of supermarkets and commercial centers in Vietnam" (Ministry of Commerce, 2004). This regulation indicated a set of requirements for goods and service products at supermarkets and commercial centers. This set established by Ministry of Commerce in 2004, includes regulations related to label, code and packaging of merchandises. Accordingly, the price of goods must be clearly marked on the packaging, labeling or in the counter.

By combining Retail service quality scale of Dabholkar with the regulation of goods at Vietnamese supermarkets; this study will assess retail service quality through 6 dimensions:

1) Physical aspects: refer to appearance of supermarket and staffs, physical equipments and facilities, visual materials for customers and the convenience at supermarket.

2) Reliability: Supermarket do right things right at the first time and always do as promised. 
3) Personal Interaction: Supermarket staffs are courteous and helpful when interact with customers; and they can build confidence in customers about their knowledge and skills.

4) Problem solving: Supermarket's willingness to handle problems such as customer complaints, merchandise returns and exchanges, and so on.

5) Policy: supermarket's policies in required quality of merchandise, convenient operating hours, free parking area, and acceptance of variety credit cards for payment.

6) Information of merchandise: label, origin, packaging of goods and price marked in each products.

Besides, this study also examines the relationship between retail service quality and customer loyalty. The analytical framework is as following:

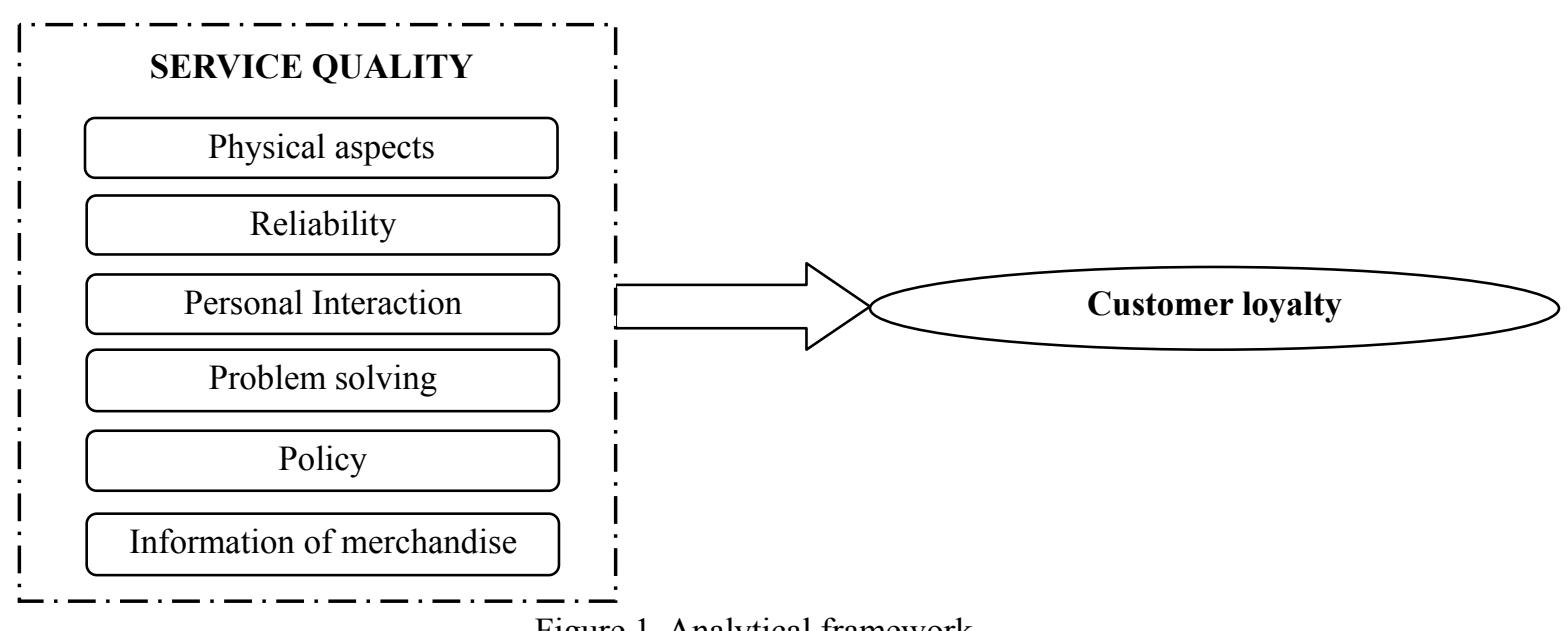

Figure 1. Analytical framework

The linkage between retail service quality and customer loyalty have been demonstrated by several previous studies such as Kitapci (2013), Beneke et al. (2012), Caruana (2002).

In this study, the role of retail service quality is expected to have positively significant influence on customer loyalty. The first hypothesis is stated as followed:

Hypothesis 1: Service quality has a positive impact on customer loyalty

Moreover, income variable is taken under consideration as a controlling variable affecting the relationship retail service quality and customer loyalty. The second hypothesis is stated as followed:

Hypothesis 2: There is a difference in the impacts retail service quality on customer loyalty among customers with different monthly income.

\section{Data Collection and Measurement Test}

\subsection{Data Collection}

Based on reviewing literature to model the analytical framework, a questionnaire was developed as an adapted version of RSQS (Dabholkar, 1996), and referenced from "Regulation of supermarkets and commercial centers in Vietnam" (Ministry of Commerce, Vietnam, 2004).

The questionnaire was divided into 3 sections:

- The first section was designed to assess the overall retail service quality perception from customers. This part includes 44 statements in total measuring 6 dimensions of retail service quality namely: Physical aspects (11 items), Reliability (4 items), Personal interaction (6 items), Problem-solving (3 items), Policy (8 items), and Product information (5 items). Besides, this part also measures the important level of the above 6 retail service quality dimensions (6 items).

- The second section aims to measure the loyalty level of customers. This variable is examined through the possibility of revisit the supermarket and whether respondents would introduce that supermarket to other people (2 items). 
- The last section consists of questions relating to demographic information about respondents such as age, gender, and income.

The first two sections are measured using a 5 point Likert rating scale which corresponding to $1=$ strongly disagree, 2 = somewhat disagree, $3=$ neither agree nor disagree, $4=$ somewhat agree, $5=$ strongly agree. This questionnaire was in Vietnamese, used to survey customers shopping at supermarkets in Hanoi, Vietnam so that they could give more meaningful responses. Survey was conducted through a direct interview method. 700 potential customers were approached and 664 feedbacks were obtained indicating a response rate as $93 \%$. All respondents are Vietnamese.

\subsection{Measurement Test}

Data collected are firstly tested to ensure the reliability through Cronbach's alpha value with the purpose to check the internal consistency. In other word, this test checks whether respondents' evaluation on any one indicator is related to their evaluation on the other indicators. In this study, the results indicate that all Cronbach's alphas values of 6 dimensions ranged from 0.794-0.884, showing high reliability level of the database.

Then, validity test is conducted to measure whether the item or scale truly measures what it is supposed to measure or nothing else. Content validity of the questionnaire is confirmed by intensive literature reviewing. The measurement items have been carefully constructed, validated and refined by Dabholkar et al. (1996) with some customizations to be suitable for the context of Vietnamese retail market. Construct validity is tested through factor analysis to ensure that the scale is an appropriate operational definition of an abstract variable (Flynn et al., 1990). In this study, within scale factor analysis is conducted for 6 service quality scales, namely Physical Aspects, Reliability, Personal interaction, Problem Solving, Policy, and Information of Merchandise, and for Customer Loyalty scale. The results reveal that the questionnaire is a valid measure of retail service quality, and customer loyalty in Hanoi, Vietnam because the items which are arranged within a scale in the questionnaire are proven under the same factors. The factor analysis results for all investigated components are presented in the following table.

Table 4. Reliability and validity tests

\begin{tabular}{lllll}
\hline Constructs & No. of Items & Cronbach's alpha & Number of factors & \% of Variance \\
\hline 1. Physical Aspects & 9 & 0.884 & 1 & 47.408 \\
2. Reliability & 4 & 0.764 & 1 & 58.706 \\
3. Personal Interaction & 4 & 0.852 & 1 & 69.391 \\
4. Problem Solving & 3 & 0.831 & 1 & 74.887 \\
5. Policy & 8 & 0.853 & 1 & 49.936 \\
6. Information of Merchandise & 5 & 0.883 & 1 & 68.356 \\
7. Customer Loyalty & 2 & 0.794 & 1 & 83.008 \\
\hline
\end{tabular}

\section{Data Analysis}

The demographic description of respondents indicates that the majority of survey participants are female with 471 out of 664 people, accounting for $70.9 \%$. Among them, the customer group at the age of 25-40 represents the largest group with $45.0 \%$ (corresponding to 299 respondents). They are the young who newly get married or have family with small children. The age group of less than 25 makes up approximately one third of total respondents. In addition, From 41 to 55 and Over 55 group accounts for smaller figure with $13.1 \%$ and $11.0 \%$, respectively.

Regarding to the income of the buyer, the largest portion fells in respondent group with monthly income at middle level ranging from USD200 to USD500 (407 respondents out of 644, corresponding to 61.2\%). This income level is slightly higher than the average income per capital of Vietnamese in 2013 (USD200 per month). This situation is suitable for the strategic development of supermarket sector which concentrates on common class in Vietnam. 
Table 5. Demographics of respondents

\begin{tabular}{llllll}
\hline Gender & & Age & & Income (per month) \\
\hline Male & $28.916 \%$ & Under 25 & $30.873 \%$ & Low income (Less than USD200) & $23.042 \%$ \\
Female & $70.934 \%$ & From 25 to 40 & $45.030 \%$ & Medium income (From USD200 to USD500) & $61.295 \%$ \\
N/A & $0.151 \%$ & From 41 to 55 & $13.102 \%$ & High income (Higher than USD500) & $16.663 \%$ \\
& & Over 55 & $10.994 \%$ & & \\
\hline
\end{tabular}

Regression analysis is conducted to test the relationship between service quality and customer loyalty of supermarkets in Hanoi. At first, mean scores of both dependent variables (customer satisfaction, customer loyalty) and independent variables (Physical Aspects, Reliability, Problem Solving, Personal Interaction, Policy, and Information of Merchandise) for 664 respondents are calculated. Then, mean scores of service quality are multiplied by weight score measuring the important level of each component which are assessed by respondents.

\subsection{Impact of Retail Service Quality on Customer Loyalty}

In examining the impact of service quality on customer loyalty of supermarket in Hanoi, R-square value indicates that $50.6 \%$ of variance in customer loyalty can be explained by 6 retail service quality variables. Moreover, significant value of 0.000 confirms that group of six service quality components have a statistically significant relationship with customer loyalty variable at the $5 \%$ significant level.

Table 6. Regression analysis on the relationship between service quality and customer loyalty

\begin{tabular}{llllll}
\hline R & 0.711 & & & & \\
R square & 0.506 & & & & \\
Sig. & 0.000 & & & \multicolumn{2}{c}{$\begin{array}{l}\text { Collinearity Statistics } \\
\text { Tolerance }\end{array}$} \\
& Beta coefficient & $\mathrm{t}$ & Sig. & VIF \\
\hline (Constant) & & & & \\
Physical Aspects & 0.279 & 2.100 & 0.036 & & 2.860 \\
Reliability & 0.288 & 6.209 & 0.000 & 0.350 & 2.884 \\
Personal Interaction & 0.069 & 1.478 & 0.140 & 0.347 & 2.956 \\
Problem Solving & 0.130 & 2.747 & 0.006 & 0.338 & 2.523 \\
Policy & 0.086 & 1.983 & 0.048 & 0.396 & 2.367 \\
Information of Merchandise & 0.158 & 3.745 & 0.000 & 0.423 & 2.274 \\
\hline
\end{tabular}

Apart from Reliability, 5 remaining service quality components express significantly positive influence on Customer loyalty at the 5\% significant level. Physical aspects which measure the appearance and convenience of the supermarket shows the strongest impact on customer loyalty with the highest coefficient value of 0.288 ., followed by supermarkets' policy on the merchandise quality, parking area, operating hours and acceptance of credit cards for payment as well as Personal Interaction measuring the truthfulness and politeness of supermarket staff with coefficient values of 0.158 and 0.130 , respectively. Additionally, information of merchandise and problem solving represent smaller impact on customer loyalty (coefficient values of 0.095 and 0.086 ). Meanwhile, Reliability is the only service quality component which express positive but not statistical impact on customer loyalty at the $5 \%$ significant level.

\subsection{Income Effects on the Relationship between Retail Service Quality and Customer Loyalty}

Retail service quality and customer loyalty are differently because of controlling variable such as income, age, visiting frequency, regions, and so on. In this section, the paper examines the influence of income on assessment of retail service quality and customer loyalty from supermarkets' respondents. The whole sample is divided into 3 groups based on the income level of respondents:

- Group 1-Lower income: includes customers with income being lower than the monthly average income per capital of Vietnamese in 2013 which is USD200 per month. 
- Group 2-Medium income: includes customers with income being higher than the monthly average income per capital of Vietnamese in 2013 which ranges from USD200 to USD500 per month.

- Group 3-Higher income: includes customers with income being 3 times higher than the monthly average income per capital of Vietnamese in 2013 which is more than USD500 per month.

Table 7. The assessment of service quality and customer loyalty in 3 groups

\begin{tabular}{lllllll}
\hline & Group 1 & Group 2 & Group 3 & F & Sig. & Pairwise Difference \\
\hline Physical Aspects & 3.664 & 3.546 & 3.555 & 4.275 & 0.014 & Group 1 vs. Group 3 \\
Reliability & 3.587 & 3.535 & 3.495 & 0.556 & 0.574 & \\
Personal Interaction & 3.358 & 3.342 & 3.283 & 0.358 & 0.699 & \\
Problem Solving & 3.351 & 3.358 & 3.260 & 0.694 & 0.500 & \\
Policy & 3.535 & 3.550 & 3.445 & 1.049 & 0.351 & \\
Information of Merchandise & 3.910 & 3.735 & 3.594 & 5.500 & 0.004 & Group 1 vs. Group 2 \\
& & & & & & Group 1 vs. Group 3 \\
Customer Loyalty & 3.734 & 3.585 & 3.481 & 3.472 & 0.032 & Group 1 vs. Group 3 \\
\hline
\end{tabular}

One-way analysis of variance (One-way ANOVA) is used to investigate if there are any significant differences between the means of three groups: Group 1-Lower income, Group 2-Medium income, Group 3-Higher income. By Tukey pairwise comparison test with the significance level at 5\%, the ANOVA result table indicates that there are some differences between Group 1 and the other two groups in customer assessment on Physical Aspects, Information of Merchandise, and Customer Loyalty. These differences indicate that the assessment of Group 1 is significant higher than Group 2 and Group 3. Regarding to the remaining components namely Reliability, Problem Solving, Personal Interaction, and Policy, the assessment from three customer groups are quite homogenous.

\section{Discussions}

This study adopted Retail Service Quality Scale (Dabholkar, 1996), and reference from "Regulation of supermarkets and commercial centers in Vietnam" (Ministry of Commerce, 2004) with some customizations to measure retail service quality at supermarket in Vietnam. The questionnaire comprises 49 items measuring 6 service quality components and customer loyalty. Data were collected from 664 customers at supermarkets in Hanoi.

Data analysis results indicated that service quality is an important driver for customer loyalty. This finding is supported by many studies such as Trang (2007) in Vietnam, Caruana (2002) in Malta, Wong \& Sohal (2002) in Australia, Bloemer et al. (1998) in Belgium, Ponirin et al. (2009) in Indonesia, Beneke et al. (2012) in South Africa, Kitapci (2013) in Turkey.

Retail Service Quality Scale was carefully developed, validated and refined by Dabholkar et al. (1996) and demonstrated being reasonable fit for retail context in many countries, namely South Africa (Christo \& Terblanche, 1997), Singapore (Mehta et al., 2000), Kazakhstan (Das et al., 2008). However, this scale was proven being inappropriate for application in Indian retail (Kaul, 2007).

In specifically, regression analysis revealed that among 6 service quality components, Physical Aspects, Problem Solving, Personal interaction, Policy, and Information of Merchandise stress statistically and positively significant impact on and customer loyalty whereas Reliability just shows its positive relationship but not statistically significant one. Especially, Personal Interaction and Physical Aspects are two factors which express the strongest impact. This is also highlighted in the study by Beneke J. et al. (2012) in South Africa. In addition, this finding is also supported by Olgun Kitapci (2013) in Turkey which stated that assurance, empathy, tangibility, and responsiveness, are factors that stress positive linkage with customer satisfaction, which in turn is positively related to customer loyalty, and by Wong, A. and Sohal, A. (2002) in Australia which stated that tangible and empathy are two most significant factors which show strongly positive relationship with customer loyalty.

Furthermore, when investigating the differences between the means of three groups-Lower income, Medium 
income, and Higher income-in their assessment of service quality component as well as their loyalty level, the result indicated that customers with lower income seem to evaluate better about some service quality component of supermarkets and also have higher loyalty level with those supermarkets.

\section{Conclusions}

In examining the impact of service quality on customer loyalty at several supermarkets in Hanoi, it can be concluded that service quality is an undeniable driver of customer loyalty and express obviously strong effects on customer loyalty level. Among 6 components of service quality, Physical Aspects, Problem Solving, Personal interaction, Policy, and Information of Merchandise indicate their statistically significant impact while Reliability does not. Moreover, the investigation of controlling factor, such as income, also find some influence on customers' evaluation which leads to differences in service quality and loyalty assessment.

The results of this study are expected to either enrich the literature of service quality management in retail sector or enhance understanding about Vietnamese retail service quality from customers' perspective. In addition, the findings could benefit quality managers of supermarket sector in Vietnam who strongly desire to improve service quality of their organizations to get competitive advantages and sustainable development.

\section{References}

Auh, \& Johnson. (2005). Compatibility effects in evaluations of satisfaction and loyalty. Journal of Economic Psychology, 26, 35-57. http://dx.doi.org/10.1016/j.joep.2003.10.002

Avkiran, N. K. (1999). An application reference for data envelopment analysis in branch banking: Helping the novice researcher. International Journal of Bank Marketing, 17(5), 206-220. http://dx.doi.org/10.1108/026 52329910292675

Babakus, E., \& Mangold, W. G. (1989). Adapting the SERVQUAL Scale to Health Care Environment: An Empirical Assessment. In P. Bloom, B. Weitz, R. Winer, R. E. Spekman, H. H. Kassarjian, V. Mahajan, D. L. Scammon, \& M. Leay (Eds.), AMA Summer Educators' Proceedings: Enhancing Knowledge Development in Marketing, Chicago, IL: American Marketing Association (p. 195).

Baker, G., \& Parasuraman. (1994). The Influence of Store Environment on Quality Inferences and Store Image. Journal of the Academy of Marketing Science, 22(4), 328-339. http://dx.doi.org/10.1177/0092070394 224002

Beneke, J., Hayworth, C., Hobson, R., \& Mia, Z. (2012). Examining the effect of retail service quality dimensions on customer satisfaction and loyalty: The case of the supermarket shopper. Acta Commercii 2012, 27-43.

Bloemer, J., Ruyter, K., \& Wetzels, M. (1998). Customer Loyalty in a Service Setting. E-European Advances in Consumer Research, 3, 162-169.

Boshoff, C., \& Terblanche, N. (1997). Measuring retail service quality: A replication study South African. Journal of Business Management, 28(4), 123-128.

Caruana, A. (2002). Service loyalty: The effects of service quality and the mediating role of customer satisfaction. European Journal of Marketing, 36(7/8), 811-828. http://dx.doi.org/10.1108/03090560210 430818

Christo, B., \& Terblanche, N. S. (1997). Measuring retail service quality: A replication study. South African Journal of Business Management, 28(4), 123-128.

Churchill, G. A. (1979). A paradigm for developing better measures of marketing constructs. Journal of Marketing Research, 16, 64-73. http://dx.doi.org/10.2307/3150876

Cronin, J. J., \& Taylor, S. A. (1992). Measuring service quality: A reexamination and extension. Journal of Marketing, 56(3), 55-68. http://dx.doi.org/10.2307/1252296

Dalholkar, P. A., Thorpe, D. I., \& Rentz, J. O. (1996). A Measure of Service Quality for Retail Stores: Scale Development and Validation. Journal of Academy of Marketing Science, 24(1).

Das, A., Saha, G. C., \& Banik, N. L. (2008). Retail Service Quality Scale: Examining Applicability in a Transition Economy. POMS 19TH Conference.

Fin, D. W., \& Lamb, C. W. (1991). In R. Holman, \& M. R. Solomon (Eds.), An Evaluation of the SERVQUAL 
Scales in a Retailing Setting. In Advances in Consumer Research (pp. 483-490). Provo, UT: Association for Consumer Research.

Fornell, C. (1992). A National Customer satisfaction barometer: The Swedish experience. Journal of Marketing, $1-21$.

Fornell, M. D., Johnson, E. W. A., Cha, J., \& Bryant, B. (1996). The American Customer Satisfaction Index: Description, Findings, and Implications. Journal of Marketing, 60(4), 7-18. http://dx.doi.org/10.2307/125 1898

Gee, G. C., \& Mike Nicholson, M. (2008). Understanding and profitably managing customer loyalty. Marketing Intelligence \& Planning, 26(4), 359-374. http://dx.doi.org/10.1108/02634500810879278

Gronroos, C. (1984). A service quality model and its marketing implication. European Journal of Marketing, 18(4), 36-44. http://dx.doi.org/10.1108/EUM0000000004784

Gutman, \& Alden. (1985). In J. Jacoby, \& J. Olson (Eds.), Adolescents' Cognitive Structures of Retail Stores and Fashion Consumption: A Means-End Chain Analysis of Quality, in Perceived Quality (pp. 99-114). Lexington, MA: Lexington Books.

Hummel, \& Savitt. (1988). Integrated Customer Service and Retail Strategy. International Journal of Retailing, $3(2), 5-21$.

Kitapci, O., Dortyol, I. T., Yaman, Z., \& Gulmez, M. (2013). The paths from service quality dimensions to customer loyalty: An application on supermarket customers. Management Research Review, 36(3), 239-255. http://dx.doi.org/10.1108/01409171311306391

Mattila, A. (1999). The Role of Culture in the Service Evaluation Process. Journal of Service Research, 1(2), 250-261. http://dx.doi.org/10.1177/109467059913006

Mazursky, D., \& Jacoby, J. (1985). Exploring the development of store images. Journal of Retailing, 62, 145-165.

Mehta, L. V. H. (2000). Service quality in retailing: Relative efficiency of alternative measurement scales for different product service environments. International Journal of Retail \& Distribution Management, 28(2), 62-72. http://dx.doi.org/10.1108/09590550010315106

Ndubisi, N. O., \& Wah, C. K. (2005). Factorial and discriminant analyses of the underpinnings of relationship marketing and customer satisfaction. International journal of bank marketing, 23(7), 542-557. http://dx.doi. org/10.1108/02652320510629908

Nhat, N. D. D., \& Hau, L. N. (2007). Determinants of retail service quality-a study of supermarkets in Vietnam. Journal of Science \& Technology Development, 10(8), 15-23.

Oliver. (1981). Measurement and Evaluation of Satisfaction Processes in Retail Settings. Journal of Retailing, 57, $25-48$.

Parasuraman, A., Zeithaml, V. A., \& Berry, L. L. (1985). A Conceptual Model of Service Quality and Its Implications for Future Research (2005). Journal of Marketing, 49(4), 41-50. http://dx.doi.org/10.2307 $/ 1251430$

Parasuraman, A., Zeithaml, V. A., \& Berry, L. L. (1988). SERVQUAL: A multi-item scale for measuring consumer perceptions of the service quality. Journal of Retailing, 64(1), 12-40.

Pfeiffer, M., \& Joel, R. (n. d.). Brand key performance indicators as a force for brand equity management. Journal of Advertising Research-New York, 45(2), 187.

Pitt, L. F., Oosthuizen, P., \& Morris, M. H. (1992). Service Quality in a High-Tech Industrial Market: An Application of SERVQUAL. American Marketing Association, 46-53.

Ponirin, P., Scott, D. R., \& von der Heidt, T. (2009). Does e-store service quality affect customer loyalty? Social Science Research Network, 11.

Rust, R. T., Zahorik, A. J., \& Keiningham, T. L. (1995). Return on quality: Making service quality financially accountable. Journal of Marketing, 59, 58-70. http://dx.doi.org/10.2307/1252073

Seth, N., Deshmukh, S. G., \& Vrat, P. (2005). Service quality models: A review. International Journal of Quality 
\& Reliability Management, 22(9), 913-949. http://dx.doi.org/10.1108/02656710510625211

Spreng, R. A., \& Singh, A. K. (1993). An Empirical Assessment of the SERVQUAL Scale, and the Relationship Between Service Quality and Satisfaction. In D. W. Peter, R. Cravens, \& Dickson (Eds.), Enhancing Knowledge Development in Marketing (Vol. 4, pp. 1-6). Chicago, IL: American Marketing Association.

Trang, N. T. M. (2006). Service quality, Satisfaction and Loyalty of customer supermarket in Hochiminh. Journal of Science \& Technology Development, 10.

Türkyilmaz, A., \& Özkan, C. (2007). Development of a customer satisfaction index model: An application to the Turkish mobile phone sector. Industrial Management \& Data Systems, 107(5), 672-687. http://dx.doi.org/10. 1108/02635570710750426

Ueltshy, L. C., \& Krampf, R. F. (2001). Cultural Sensitivity to Satisfaction and Service Quality Measures. Journal of Marketing Theory and Practice, 9(3), 14-31.

Westbrook et al. (1981). Developing Better Measures of Consumer Satisfaction: Some Preliminary Results. In K. B. Monroe (Ed.), Advances in Consumer Research (Vol. 8, pp. 94-99). Arlington, VA: Association for Consumer Research.

Wong, A., \& Sohal, A. (2002). Customers' perspectives on service quality and relationship quality in retail encounters. Managing Service Quality, 12(6), 424-433. http://dx.doi.org/10.1108/09604520210451902

Zeithaml, V. A. (1996). The behavioral consequences of service quality. Journal of Marketing, 60(2), 31-46. http://dx.doi.org/10.2307/1251929

\section{Copyrights}

Copyright for this article is retained by the author(s), with first publication rights granted to the journal.

This is an open-access article distributed under the terms and conditions of the Creative Commons Attribution license (http://creativecommons.org/licenses/by/3.0/). 